doi:10.18575/msrs.sm.s.16.14 UDK: 616-00\%.52 COBISS.RS-ID: 5700888

\title{
Odgovor na terapiju mikofenolat mofetilom kod pacijentice sa teškim oblikom sistemskog eritemskog lupusa
}

\section{SAŽETAK}

Sistemski eritemski lupus (SEL) je bolest nepoznate etiologije u kojoj su tkiva i ćelije oštećeni patogenim autoantitijelima i imunskim kompleksima. 90\% oboljelih su žene, a starosna dob u kojoj najčešće oboljevaju je između 20. i 40. godine života. Bolest može zahvatiti samo jedan organski sistem, a može biti i višesistemska i zahvatiti kožu, zglobove, bubrege, pluća, nervni sistem i serozne membrane. U radu je prikazan slučaj 38-ogodišnje pacijentice sa teškim oblikom sistemskog eritemskog lupusa, koji je adekvatno odreagovao na terapiju mikofenolat mofetilom.

KIjučne riječi: Sistemski eritemski lupus, efekat terapije, mikofenolat mofetil

(Scr Med 2016:47:77-78)
Ljubinka BožićMajstorović, Branislav Gašić, Darko Jović, Marina Vukčević, Jela Aćimovićc ${ }^{2}$

${ }^{1}$ Klinika za unutrašnje bolesti, Univerzitetski klinički Centar Republike Srpske, Banja Luka

${ }^{2}$ Institut za javno zdravstvo, Banja Luka

\section{Kontakt adresa:}

Ljubinka Bozić-Majstorović Adresa: J.G.Zmijanjke 63

Telefon: +38765524520

E-mail: bubao210@gmail.com

Rad primljen: 25.1.2016. Rad prihvaćen: 12.2.2016.

\section{Uvod}

Sistemski eritemski lupus (SEL) je bolest nepoznate etiologije u kojoj su tkiva i ćlije ostećeni patogenim autoantitjelima i imunskim kompleksina. ${ }^{1}$ go\% oboljelił su žene, obično u reproduktivnom periodu žvota, ali i djeca, muškarci i stare osobe takođe mogu da obole. ${ }^{2}$ SEL se ispoljava subjektivnim i kliničkim znakowima najčešce na koži, zglobovima i unutrašnjim organima. Dobro poznavanje pacijenta i spoznaja o aktiwnosti njegowe bolesti te tokı bolesti odlučujući su faktori pri izboru medikamentne terapije: salicilatima, nesteroidnim antireumaticima, antimalaricima, kortikostercidima, iпnпоsup геsivтim agensima i monoklonskim antitijelima. ${ }^{3}$

\section{Prikaz slučaja}

Pacijentica stara 38 godina javila se u martu 2009-godiпе па Odjeljenje reumatologije zbog lošeg opšteg stanja, slabosti $\mathrm{i}$ bolova u zglobovima i mišićima. U anamnezi je dobijen podatak da se od avgusta 2007. godine liječila pod dijagnozom seronegativnog reumatoidnog artritisa, a u terapiju su bile uključene niske doze kortikosteroida i hidroksihlorokvina. Pacijentica nije bila na redownim kontrolama duži vremenski period.

U objektivnon nalazu vidljive su shınice i uočena je blijeda koža, leptirasti eritem na koži lica, tjestasti edemi potkoljenica i dorzuma stopala, kao i sinowitis talokruralnih zglobowa. U laboratorijskim nalazima dominirala je teša anemija sa vrijednostima eritrocita $0.41 \times 10$ 12/1 i hemoglobina $4.8 \mathrm{~g} / \mathrm{dl}$, povišene vrijednosti proteina u urinu, $4.8 \mathrm{gr} / 24 h$, snižen klirens kreatinin, $49 \mathrm{ml} / \mathrm{min}$, pozitivne bjelančevine $(+++)$ u urinu, snižene vrijednosti konponente komplementa, pozitivan titar ANA, anti-dsDNA pozitivan, >200IU/ml i anti-ssDNA pozitivan, > 200IU/ ml. Tokom hospitalizacije pacijentica je liječena sa me- 
tilprednizolonom u dozi od $1 \mathrm{mg} / \mathrm{kg} \mathrm{TT}$, antibioticima $\mathrm{i}$ transfuzijama deplazmatisanih eritrocita. Sedmog dana hospitalizacije u terapiju je uveden mikofenolat mofetil u dozi 2000 mg dnevno. Na početku liječenja nije se odlučilo na uwođenje pulsne terapije ciklofosfamidon zbog niskih vrijednosti crvene krvne loze. Dvadesetog dana liječenja dolazi do dodatnog pogoršanja bolesti (ponowni pad u crvenoj krvnoj lozi). Nakon ustanowljenog pogoršanja u hematopoeznom sistemu, odlučili smo se na ordiniranje pulsne terapije metilprednizolonom u dnevnoj dozi od 1000 mg parenteralno u trajanju tri dana, nakon čega je postignuta stabilnost u crvenoj krvnoj lozi. Nakon liječenja u bolnici, i dalje su ostale visoke vrijednosti proteina u urinu $3-4 \mathrm{gr} / 24 \mathrm{~h}$ i snižene vrijednosti klirens kreatinina $31 \mathrm{ml} / \mathrm{min}$. Pacijentica je otpuštena sa preporukama o terapiji kortikosteroidima, mikofenolat mofetilom, hidroksihlorokvinom, osteoporotičnom zaštiton i antiagregacionom terapijom. Pacijentica dolazi na redowne kontrole i na zadnjoj, u septembru 2015-godine, vrijednosti proteina u urinu i klirens kreatinin, kao i ostali laboratorijski parametri su bili u granicama referentnih vrijednosti.

\section{Diskusija}

Slučaj prikazane pacijentice je razmatran u smislu postavjjanja dijagnoze sistemskog eritemskog lupusa u skladu sa kriterijima za postavljanje dijagnoze te izuzetno powoljnog terapijskog odgowora nakon pulsne terapije metilprednizolonom i kontinuirane terapije mikofenolat mofetilon. Simptoni i znakovi su u našen slučaju zadovoljavali kriterije za postavljanje dijagnoze. Kod pacijentice su postojala 6 od ukupno jedanaest kriterijuna za klasifikaciju sistenskog eritemskog lupusa i to: leptirasti eritem, artritis, bubrežni poremećaji, hematološki poremećaji, pozitivna antinukleusna antitijela i pozitivna anti-dsDNA i anti-ssDNA antitijela. ${ }^{4}$ Rad je prikazan zbog značaja ranog postavljanja dijagnoze sistemskog eritemskog lupusa te ranog agresivnog liječenja.

\section{Zaključak}

Zbog nemogućnosti da se uradi biopsija bubrega, za postizanje dugotrajne remisije bolesti vrlo je značajna kliničko-laboratorijska procjena u individualnom terapijskom pristupu ovakvim pacijentima. U radu je prikazana pacijentica koja je па pravovremenu primjenjenu agresivnu terapiju pulsnim dozama metilprednizolona i visokim dozama mikofenolat mofetila postigla potpunu laboratorijsku i kliničku remisiju bolesti.

\section{Reference}

1. Harissonova načela interne medicine. 15. Izdanje. Eugene Braaunvald (et al)-Beograd:Bard - fin ; Bamja Luka:Romanoy 2004 Knjiga 2. $311: 1922$

2. Schur PH. Owerviev of clinical manifestations of the systemic lupus eritematodus in adults. Dostupno na www.uptodate. com.

3. Austin HA, Balow JE:Natural history and treatment of lupus nephritis. Semin Nephrol 19:2,1999. PMid:9952276

4. Egner W. The use laboratory testes in the diagnosis of SEL. J Clin Pathol 2000553:424-32.

http://dx.doi.org/10.1136/jep.53.6.424 PMid:10911799 PWCd:PMC1731203

\title{
Response to Mycophenolate Mofetil Therapy in the Patient with Severe Systemic Lupus Erythematosus
}

\begin{abstract}
Systemic lupus erythematosus (SLE) is a disease of unknown etiology in which tissues and cells are damaged by pathogenic autoantibodies and immune complexes. About ninety percent of patients with lupus are women between the ages of 20 and 40. The disease may affect only one organ system, and it also can be a multisystem and affect the skin, joints, kidneys, lungs, nervous system, and serous membrane. In the case report is presented a 38 year old patient with severe systemic lupus erythematosus, which adequately reacted to the treatment of mycophenolate mofetil.
\end{abstract}

Keywords: Systemic lupus erythematosus, the effect of therapy, mycophenolate mofetil. 